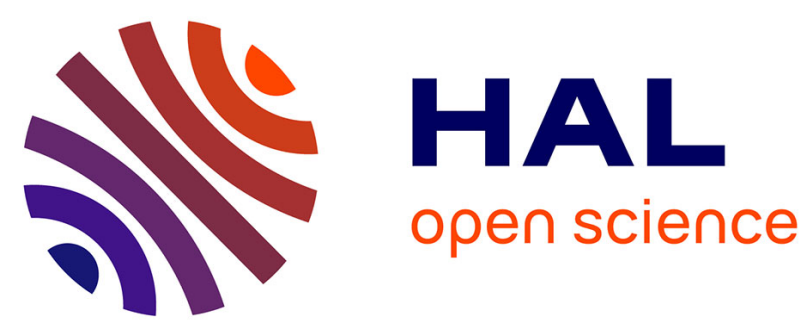

\title{
A novel codrug made of the combination of ethionamide and its potentiating booster: synthesis, self-assembly into nanoparticles and antimycobacterial evaluation
}

\author{
Alexandra Pastor, Arnaud Machelart, Xue Li, Nicolas Willand, Alain
} Baulard, Priscille Brodin, Ruxandra Gref, Didier Desmaele

\section{To cite this version:}

Alexandra Pastor, Arnaud Machelart, Xue Li, Nicolas Willand, Alain Baulard, et al.. A novel codrug made of the combination of ethionamide and its potentiating booster: synthesis, self-assembly into nanoparticles and antimycobacterial evaluation. Organic \& Biomolecular Chemistry, 2019, 17 (20), pp.5129 - 5137. 10.1039/c9ob00680j . hal-03009695

\section{HAL Id: hal-03009695 \\ https://hal.science/hal-03009695}

Submitted on 2 Dec 2020

HAL is a multi-disciplinary open access archive for the deposit and dissemination of scientific research documents, whether they are published or not. The documents may come from teaching and research institutions in France or abroad, or from public or private research centers.
L'archive ouverte pluridisciplinaire HAL, est destinée au dépôt et à la diffusion de documents scientifiques de niveau recherche, publiés ou non, émanant des établissements d'enseignement et de recherche français ou étrangers, des laboratoires publics ou privés. 


\title{
ARTICLE
}

\section{A novel codrug made of the combination of ethionamide and its potentiating booster: Synthesis, self-assembly into nanoparticles and antimycobacterial evaluation}

Received 00th January 20xx, Accepted 00th January 20xx DOI: $10.1039 / x 0 x \times 00000 x$

\begin{abstract}
Alexandra Pastor, ${ }^{a}$ Arnaud Machelart, ${ }^{\mathrm{b}}$ Xue Li, ${ }^{\mathrm{c}}$ Nicolas Willand, ${ }^{\mathrm{d}}$ Alain Baulard, ${ }^{\mathrm{b}}$ Priscille Brodin, ${ }^{\mathrm{b}}$ Ruxandra Gref ${ }^{c}$ and Didier Desmaële, ${ }^{* a}$

Ethionamide $(\mathrm{ETH})$ is one of the most widely used second-line chemotherapeutic drugs for the treatment of multi-drugresistant tuberculosis. The bioactivation and activity of ETH is dramatically potentiated by a family of molecules called "boosters" among which BDM43266 is one of the most potent. However, the co-administration of these active molecules is hampered by their low solubility in biological media and by the strong tendency of ETH to crystallize. A novel strategy is proposed here consisting in synthesizing a codrug able to self-associate into nanoparticles prone to be taken up by infected macrophages. This codrug is designed by tethering $N$-hydroxymethyl derivatives of both ETH and its booster through a glutaric linker. This codrug self-assembles into nanoparticles of around $200 \mathrm{~nm}$, stable upon extreme dilution without disaggregating as well as upon concentration. The nanoparticles of the codrug can be intranasally administered overcoming the unfavorable physico-chemical profiles of the parent drugs. Intrapulmonary delivery of the codrug nanoparticles to $M t b$ infected mice via intranasal route at days 7, 9, 11, 14, 16 and 18 post-challenge reduces bacterial load in the lungs by a factor of 6.
\end{abstract}

\section{Introduction}

The Tuberculosis (TB) is a leading infectious cause of death worldwide. About one-third of the world's population is infected with Mycobacterium tuberculosis (Mtb), the bacterium that causes TB. Ethionamide $(E T H, 1)$ is one of the most widely used second-line chemotherapeutic drugs for the treatment of multi-drug-resistant TB (MDR-TB). ${ }^{1-3}$ ETH inhibits the mycobacterial enoyl-acyl carrier protein reductase InhA, thus impairing the biosynthesis of mycolic acids, essential components of the bacterial wall. ${ }^{4}$ Although the emergence of MDR-TB makes second line TB drugs become increasingly important, ETH suffers from a low therapeutic index and high rates of dose-dependent drug adverse effects, including nausea, abdominal pain, liver and thyroid complications. ${ }^{5}$ ETH is actually a prodrug which is converted into its active nicotinamide adenine dinucleotide (NAD) adduct inside the

\footnotetext{
a. Institut Galien Paris-Sud, UMR 8612, CNRS, Université Paris-Sud, Faculté de Pharmacie, 5 rue JB Clément, 92296 Châtenay-Malabry, France

E-mail: didier.desmaele@u-psud.fr.

${ }^{b .}$ Université de Lille, CNRS, Inserm, CHU Lille, Institut Pasteur de Lille, U1019

UMR8204 - CIIL - Center for Infection and Immunity of Lille, F-59000 Lille, France. c. Institute of Molecular Sciences, UMR CNRS 8214, Université Paris-Sud, 91400 Orsay, France.

${ }^{d .}$ Université de Lille, Inserm, Institut Pasteur de Lille, U1177 - Drugs and Molecules for Living Systems, F-59000 Lille, France

† Footnotes relating to the title and/or authors should appear here.

Electronic Supplementary Information (ESI) available: [details of any supplementary information available should be included here]. See DOI: $10.1039 / x 0 x x 00000 x$
}

mycobacteria by EthA, a flavin-containing Bayer-Villiger monooxygenase enzyme that oxidizes ETH into its S-oxide derivative and then into reactive radicals. ${ }^{6}$ The production of EthA is controlled by the transcriptional repressor EthR. The latter limits the expression of EthA and thereby the bioactivation of $\mathrm{ETH}^{7}{ }^{7}$ The sensitivity of Mtb to ETH can be enhanced by using small-molecule inhibitors of EthR that allosterically inactivate its DNA-binding activity. The discovery of efficient EthR inhibitors that when used in combination with ETH allowed to dramatically increase the in vitro and in vivo potency of ETH and to reduce its side effects was a major advance. ${ }^{8,9}$ Among them, BDM43266 has been identified as a potent ligand of EthR allowing at low concentration $(80 \mathrm{nM})$ to increase by 10 fold the $M t b$ growth inhibition by ETH in macrophages (Fig. 1). ${ }^{10}$ However the co-administration of ETH/BDM43266 combination regimen is hampered by the poor water solubility of both compounds accentuated by the propensity of ETH to crystallize. $^{11,12}$ The simultaneous delivery of two drugs, while maintaining an appropriate concentration, is a difficult challenge because when compounds, with dissimilar pharmacokinetics, are administered together as a physical mixture they are transported to the site of action with different efficiencies. As a result the expected additive therapeutic effects are not optimal while concurrently the risk of adverse effects increases. ${ }^{13}$ 


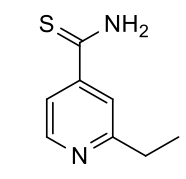

Ethionamide (1)

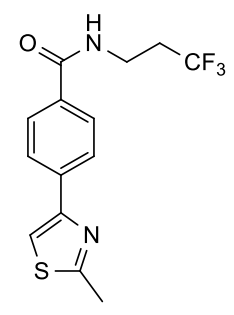

BDM43266 (2)
Fig. 1 Structure of ethionamide and of its BDM43266 booster

The design of a codrug is thought to offer a potential and effective implement for addressing this issue. Codrugs consist of two different synergetic drugs joined together in a single entity directly or through a linker designed to release the parent drugs by metabolic bio-transformations. ${ }^{14,15}$ In the present case the ETH/BDM43266 codrug would optimally embed self-assembling properties allowing direct pulmonary delivery. Direct administration of anti TB drugs into lungs is a promising approach to improve the efficiency of the treatments as it increases drug concentration at the infection site while minimizing systemic toxic effects. ${ }^{16}$ It must be emphasized that the high crystallinity of ETH added to the low solubility of BDM43266 completely impaired the coadministration by nebulization of a physical mixture of the two drugs directly into the lungs. To address this problem, cyclodextrin-based nanocarriers able to encapsulate simultaneously ETH and BDM43266 with a 5 wt\% drug loading have recently been developed. ${ }^{17,18}$ The nanocarriers of around $10 \mathrm{~nm}$ were found non-toxic and suitable for pulmonary administration by nebulization directly into the lungs. In this study, we attempted to go steps further by elaborating nanocarriers practically made of pure drugs. The challenge was to couple ETH and its booster in such a way that the novel bioconjugate would self-assemble under the form of nanoparticles prone to be taken up by infected macrophages. We report herein a full account of the synthesis of a mutual prodrug of ETH and its BDM43266 potentiating booster bound together through a potentially cleavable linker and its formulation as stable nanoparticles through spontaneous selfassembling of the codrug leading to a total of $78 \mathrm{wt} \%$ drug content. Moreover, we disclose a first in vivo proof of concept of the therapeutic efficacy of the codrug nanoparticles against TB after intranasal administration in a model of $M t b$-infected mice.

\section{Results and Discussion}

\section{Synthesis of the ethionamide-booster codrug (ETH-B)}

The design of prodrug from molecules possessing hydroxyl, amino, carboxylic acid groups or other available acidic functions is well established. In the present case the two drugs display only amide and thioamide groups respectively. Most known prodrug forms for amide drugs are $\mathrm{N}$-acyl derivatives that suffer from the low regioselectivity of the cleavage of the corresponding imide. ${ }^{19}$ Alternatively, Mannich bases or $\mathrm{N}$ hydroxyalkyl derivatives have been proposed but in spite of the fact that a number of potentially useful prodrugs were prepared, very few compounds have been marketed to date. ${ }^{20-}$ $22 \mathrm{~N}$-acyloxyalkyl prodrugs appear as the most promising strategy, combining chemical stability and easy release upon exposure to esterase via the corresponding hydroxyalkyl derivative. $^{23}$

Thus, we initially chose to synthetize the bis- $N$-acyloxyalkyl prodrug 3, anticipating that esterases should release the hydroxyalkyl derivative of both drugs (4 and 5) that should then decompose into ETH and BDM43266 by release of formaldehyde at physiological $\mathrm{pH}$ according to a base catalysis mechanism. Formaldehyde is produced endogenously by various oxidative demethylation reactions catalyzed by cytochromes, low levels of formaldehyde exists in vivo and exogenous formaldehyde is produced by currently marketed drugs such as pivampicillin, methenamine or rolitetracycline. ${ }^{24}$ Considering the hydrophobic character of the BDM43266 bearing a trifluoropropyl appendage we may expect its coupling with the more polar ethionamide through a polyoxygenated spacer to give an amphiphilic conjugate embedding self-assembling properties. Furthermore by modulating the diacid linker between the two drugs it will be possible to adjust the amphiphilic balance and the distance between both entities (Scheme 1).

To start our synthesis, we first examined the formation of the $\mathrm{N}$-hydroxymethyl derivative 4 from ETH (1). In the event, treatment of 1 by a large excess of formalin (25 equiv. of formaldehyde 37 wt. \% in $\mathrm{H}_{2} \mathrm{O}$ ) as reported by Böhme and Hotzel $^{[25,26]}$ provided the desired hemiaminal 4 but accompanied by many side products and formaldehyde polymers. Upon reducing the amount of formalin to 4 equiv. a $56 \%$ yield of 4 was achieved after chromatographic purification.

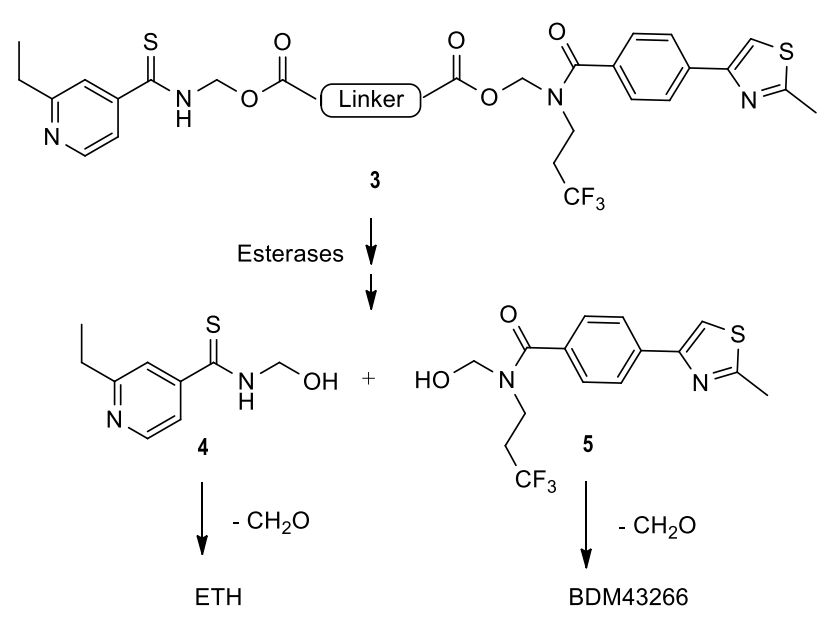

Scheme 1 General structure of the ethionamide-BDM43266 codrug 3 and hypothetical mechanism of the release of the parent drugs. 
Unfortunately, the same procedure failed to furnish the corresponding hydroxymethyl derivative $\mathbf{5}$ from the BDM43266 amide $\mathbf{2}$ whatever the conditions tested. Likewise, reaction of $\mathbf{2}$ with paraformaldehyde and $\mathrm{Me}_{3} \mathrm{SiCl}$ according to the method of Majumdar et al. ${ }^{27}$ did not give the expected $\mathrm{N}$ chloromethyl derivative $\mathbf{6 d}$. We therefore turned our attention to $\mathrm{N}$-alkylative procedures. Unfortunately, alkylation of the anion derived from amide $\mathbf{2}$ upon treatment with potassium bis(trimethylsilyl)amide (KHMDS) and various electrophiles including (chloromethoxy)tris(propan-2-yl)silane or acetic acid chloromethyl ester failed to provide the expected derivatives $\mathbf{6 a}$, or $\mathbf{6 b}$. $^{28,29}$ It was finally found that exposure of amide $\mathbf{2}$ to chloromethyl methyl ether and $t$-BuOK in solid-liquid phase transfer conditions as reported by Danikiewicz et al. delivered $6 c$ in $61 \%$ yield. $^{30}$ Interestingly, although a complete conversion was observed after a few minutes reaction, reversion to the starting material occurred upon longer reaction times. This method allowed the functionalization of the booster amide group of BDM43266 but did not provide any handle to tether the ETH moiety. To address this problem we speculated that treatment of $\mathbf{6 c}$ with a Lewis or a Brønsted acid should deliver the $\mathrm{N}$-acyliminium ion $\mathbf{7}$ that might further react with a suitable nucleophile. To check this idea compound 6c was treated with succinic acid in the presence of $\mathrm{TsOH}$ as catalyst, but only reversion of the starting material to $\mathbf{2}$ was observed. Likewise, all attempts to acylate the $\mathrm{N}$ hydroxymethyl derivative $\mathbf{6 d}$, available in low yield along amide 2 by direct hydrolysis with $0.1 \mathrm{~N} \mathrm{HCl}$ of the methoxymethyl derivative $6 \mathrm{c}$, with various reagent induced only reversion to starting amide $\mathbf{2}$. Reversing the polarity of the two partners was also fruitless. For example $\mathrm{SOCl}_{2}$ treatment of $\mathbf{6 c}$ provided the chloromethyl derivative $6 \mathrm{~d}$ in moderate yield together with some starting amide $\mathbf{2}$. However, $\mathrm{S}_{\mathrm{N}} 2$ displacement of the chloride $\mathbf{6} \mathbf{d}$ with cesium propionate used as a simple carboxylate model did not afford the expected acyloxymethyl adduct but once again reversion to the starting amide 2, while the same method was found successful on a simple $\mathrm{N}$-chloromethylbenzamide model (Scheme 2).

All attempts to introduce the desired $N$-(acyloxymethyl) carboxamide group having failed, we thus turned our attention to the introduction of a simple hemiaminal linker that might ultimately be hydrolyzed in vivo as it was shown for other alkoxymethyl prodrugs. $^{31,32}$ Thus, treatment of $\mathbf{6 c}$ with ethylene glycol in the presence of a catalytic amount of $\mathrm{TsOH}$ was attempted. However, no reaction was observed. This apparent lack of reactivity was attributed to the significant basicity of the thiazole ring [pKa 2.54 (Marvin Sketch)]. Accordingly, when the same reaction was conducted in the presence of 1.1 equiv of $\mathrm{TsOH}$ the desired alcohol 8 was obtained in $80 \%$ yield (Scheme 2 ). Introduction of the diacid linker was next examined. To this aim, the hemiaminal 4 was condensed with glutaric anhydride to give acid 9 in $91 \%$ yield. Unexpectedly, when acid $\mathbf{9}$ was reacted with the booster derivative 8 using dicyclohexylcarbodiimide (DCC) as coupling agent, the ethionamide-booster conjugate (ETH-B) was not observed. Instead, a complex mixture was obtained in which the only identified products were the hemiglutarate ester of alcohol 8 and some starting amide 2 . The same result was obtained with a large range of coupling agents. Suspecting some instability of the activated form of the acid $\mathbf{9}$, we decided to reverse the partners in the final coupling. To this aim, the alcohol $\mathbf{8}$ was first reacted with glutaric anhydride to give $\mathbf{1 0}$ in $74 \%$ yield. Condensation of acid $\mathbf{1 0}$ with the ETH hemiaminal 4 using $\quad N$-(3-dimethylaminopropyl)- $N^{\prime}$-ethylcarbodiimide. $\mathrm{HCl}$ /hydroxy-benzotriazole (EDCl/HOBt) as coupling agent, provided the desired codrug ETH-B but in minute amount. A large variety of coupling agents (DCC, 4-(4,6-dimethoxy-1,3,5triazin-2-yl)-4-methylmorpholinium chloride (DMTMM), hexafluorophosphate azabenzotriazole tetramethyluronium (HATU), mixed anhydride using $\mathrm{ClCO}_{2} \mathrm{Et}$, acid chloride obtained upon $\mathrm{ClCOCOCl}$ or $\left(\mathrm{CH}_{3}\right)_{2} \mathrm{C}=\mathrm{CCINMe}$ treatment, etc.) was tested but improving only marginally this result. It was ultimately found that reaction of the thiazole ring with the activated species was the main cause of the problem.

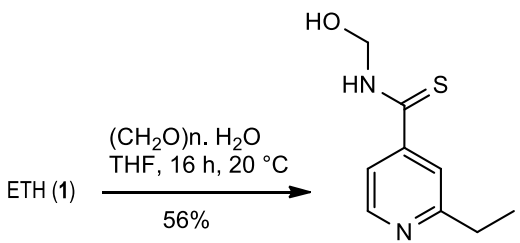

4

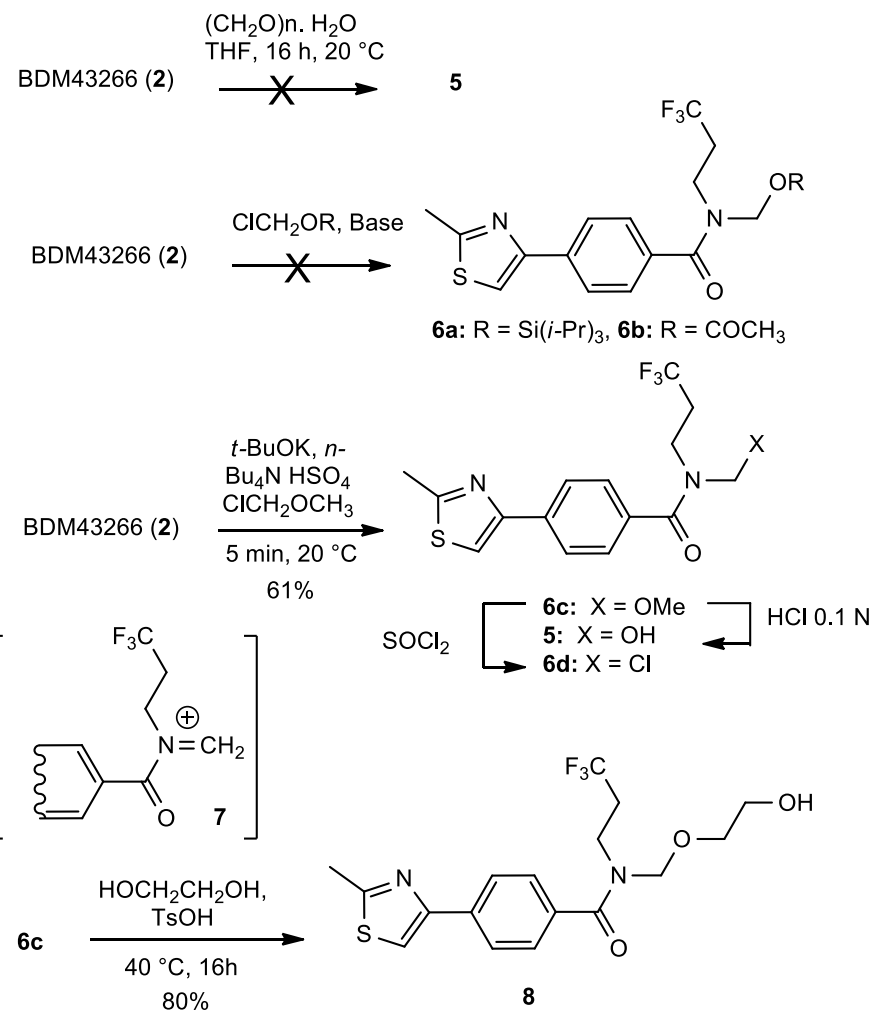

Scheme 2 Synthesis of $\mathrm{N}$-hydroxymethyl derivatives of ethionamide and functionalization of the BDM43266 booster 
<smiles>CCc1cc(C(=S)NCO)ccn1</smiles><smiles>CCCOCN(CCC(F)(F)F)C(=O)c1ccc(-c2csc(C)n2)cc1</smiles>
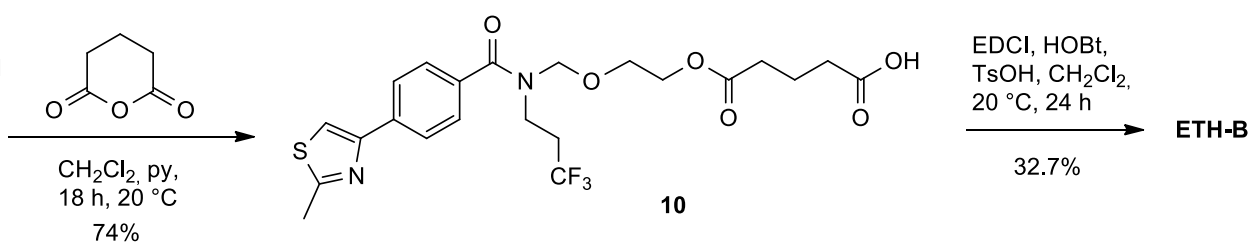

Scheme 3 Attempted synthesis of the ETH-B codrug by tethering the glutaric spacer on the $\mathrm{N}$-hydroxymethyl ethionamide derivative $\mathbf{4}$ and final synthesis of the ETH-B codrug

We therefore decided to add a proton source to protonate the nitrogen atom of the thiazole during the coupling, keeping in mind that the hemiaminal function is strongly acid sensitive.

In the event when the standard EDCl coupling was conducted in the presence of 1.2 equiv. of $\mathrm{TsOH}$ the desired ester was obtained in $32.7 \%$ yield after chromatographic purification. Thus, although the yield of the final coupling step needs to be improved, this synthetic route represented an acceptable synthesis of the codrug ETH-B for formulation studies and preliminary biological evaluation (Scheme 3).

\section{Nanoparticle formulation}

ETH-B NPs were formed by simple nanoprecipitation in water and were shown to possess spherical shapes and uniform morphologies as determined by cryogenic transmission electron microscopy (cryo-TEM) (Fig. 2). They were found malleable, adapting their shape to the copper grid used for cryo-TEM, but did not stick to each other, possibly because the surface of the NPs was covered by polyvinyl alcohol (PVA), which was added in the aqueous solution (1 wt. \%) as emulsifying agent for nanoprecipitation. The NPs prepared at ETH-B $1 \mathrm{mg} / \mathrm{mL}$ concentration were further characterized by Nanoparticle Tracking Analysis (NTA) showing a mean diameter of $195 \pm 28 \mathrm{~nm}$. NTA is a method of choice as it allows detecting individual NPs in their Brownian motion so that mean diameters can be calculated from NPs trajectories. In this study, around 5000 NPs were detected allowing obtaining statistically relevant data.
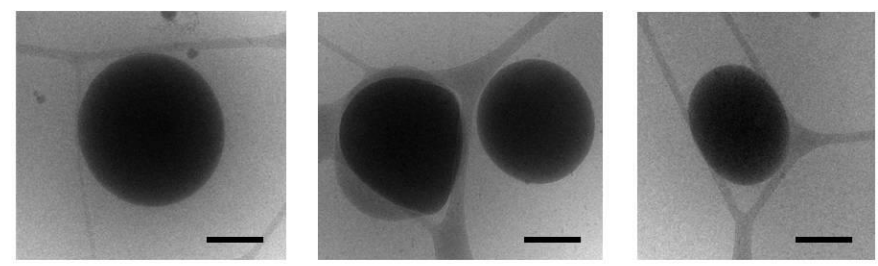

Fig. 2 Typical cryoTEM images of EthB NPs deposited on a copper grid. Scale bar represents $100 \mathrm{~nm}$.
It was also found that the ETH-B NPs were stable upon storage at $4{ }^{\circ} \mathrm{C}$ for one week with less than $8 \%$ diameter changes $(210$ $\pm 31 \mathrm{~nm}$ after one week storage). Proton NMR investigations were carried out to study NP integrity after preparation to detect any possible degradation of the codrug. For this, NP suspensions were centrifuged after their preparation, pellets and supernatant were recovered and submitted to ${ }^{1} \mathrm{H}$ NMR investigations. Less than $1 \mathrm{wt} \%$ of codrug was found in the supernatants, showing that the new hydrophobic ETH-B bioconjugate efficiently associated to form the NPs. The NPs recovered in the pellets have identical composition as the starting ETH-B conjugate, demonstrating that no degradation or hydrolysis occurred during NP preparation.

To reach the optimal therapeutic drug concentration, the increase in the concentration of NPs has been investigated. Thus, when NP suspensions, initially at $1 \mathrm{mg} / \mathrm{mL} \mathrm{ETH-B} \mathrm{were}$ concentrated up to $8 \mathrm{mg} / \mathrm{mL}$ under nitrogen flow, their size was only slightly modified, from $195 \pm 28 \mathrm{~nm}$ to $208 \pm 34 \mathrm{~nm}$ after concentration. This supported the fact that the ETH-B NPs did not aggregate upon high concentration. It was further interesting to study the stability of the NPs upon high dilution, in order to detect a possible disassembling effect. For this, NPs were diluted 1000 fold, from an initial concentration of 1 $\mathrm{mg} / \mathrm{mL}$ ETH-B down to only $1 \mu \mathrm{g} / \mathrm{mL}$, and their size distributions was analyzed by NTA. A typical size distribution is shown in Fig. 3A, indicating a mean diameter of around $195 \pm$ $28 \mathrm{~nm}$ with narrow size distribution. In the concentration range suitable for NTA, it was found that the NP size remained constant whatever the dilution (Fig. 3B). Moreover, the number of NPs per volume unit of suspension media was calculated and related to the mass of ETH-B in the same volume. Remarkably the ratio NP number/mass of ETH-B remained constant, indicating that the NPs were not destabilized (divided or aggregated). These results supported the good stability of the ETH-B codrug NPs, even upon extreme dilution, suggesting their suitability for further in vivo studies. 

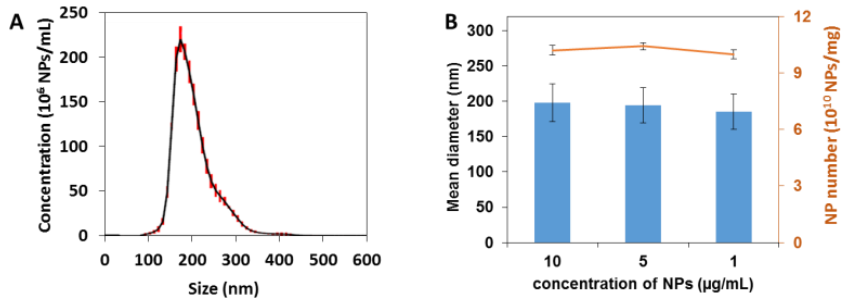

Fig. 3 Mean hydrodynamic diameters and concentration of ETH-B NP suspensions upon dilution. A. Size distribution of ETH-B NPs at a concentration of $1 \mu \mathrm{g} / \mathrm{mL}$. Error bars are shown in red and were calculated as averages on 5 measurements. B. Mean hydrodynamic diameters (blue) and number (orange) of ETH-B NPs upon dilution. NP number corresponds to the number of NPs formed by a determined mass ( $1 \mathrm{mg}$ ) of ETH-B codrug and takes into account the dilution factor. It was directly determined by NTA by counting at least 5000 particles at concentrations of 1,5 and $10 \mu \mathrm{g} / \mathrm{mL}$.

Moreover, the ETH-B codrug NPs were found to be stable in physiological media complemented with a model protein, human serum albumin, at $\mathrm{pH}$ ranging from 1.2 to 7.4 , suggesting their suitability for further in vivo studies (Table S1).

\section{In vivo evaluation in a model of $M t b$ infected mice}

ETH and BDM43266 could not be administered in vivo into the lungs of infected mice without the need of an appropriate carrier, in reason of the hydrophobicity of these compounds and of the strong tendency of ETH to crystallize. ${ }^{18}$ Herein, we address this challenge by using stable ETH-B NPs of around 200 $\mathrm{nm}$. The NPs could be concentrated to ETH-B concentration of $8 \mathrm{mg} / \mathrm{mL}$ and administered by intranasal route to infected mice (Fig. 3). It is worth mentioning that in order to administer equivalent amounts of ETH, this drug needs to be solubilized and a mixture of DMSO: water containing around $40-50 \mathrm{vol} \%$ DMSO is needed. ${ }^{18}$ This elevated amount of organic solvent is poorly compatible with an in vivo administration. Keeping in mind that alveolar macrophages are reservoirs for Mtb, another advantage of the ETH-B NPs is their size of around 200 $\mathrm{nm}$, prone to induce macrophage uptake to target the bacteria within host cell. ${ }^{33}$ To study the efficacy of ETH-B NPs, mice were inoculated with $M t b \mathrm{H} 37 \mathrm{Rv}$ via the intranasal (i.n.) route and then mice received six administrations via gavage (gav.) or i.n. route at days $7,9,11,14,16$ and 18 post-challenge (Fig. 4A). Contrary to gavage treatment which has no effect to contain Mtb burst, intranasal administration, allowed to reduce bacterial load in the lungs by a factor of 6 (Fig. 4B). This result demonstrated the benefit of using the pulmonary route of infection to target more specifically $M t b$ within reservoir cells. Using the same experimental design, we recently showed that ETH itself is ineffective when given intranasally in lungs during two weeks, ${ }^{34}$ therefore a 6 -fold reduction of the bacterial burden obtained after only 6 administrations of ETHB NPs is encouraging. The next studies will aim at investigating whether an increase in the treatment duration or in the amount of administrated drugs could improve ETH-B efficacy. When compared with other strategies of ETH/BDM administration using nanocarriers, the use of ETH-B codrug ensures simultaneous delivery of both drugs at the site of $M t b$ infection. Taken together, our results suggested that the pulmonary administration of ETH-B NPs could be a promising strategy to improve current anti-Mtb therapy in humans leading to a decrease of the antibiotics daily dose and the treatment duration. Such a non-invasive treatment could also be used to decrease the bacterial load in patients arriving at the hospital, in order to protect the staff and the family in contact.

\section{Conclusions}

In summary, an efficient synthesis of the ETH-B codrug of ETH and BDM43266 has been devised in which the key steps are the hydroxymethylation of both drugs. The obtained codrug was found able to self-assemble into NPs of around $200 \mathrm{~nm}$ which were remarkably stable either upon concentration (8 $\mathrm{mg} / \mathrm{mL}$ ) or dilution $(1 \mu \mathrm{g} / \mathrm{mL})$. Noticeably, the yield of $\mathrm{NP}$ formation was close to $100 \%$ in reason of the hydrophobicity of the new compound and no degradation occurred during NP preparation. The formed nanoparticle displayed an impressive drug loading of almost $80 \%$. The suspension was suitable for administration directly to the lungs of infected mice, reducing the bacterial load by a factor of 6 . We believe that this strategy can be extended to other synergistic drug combinations setting the way for promising therapeutic applications.

A

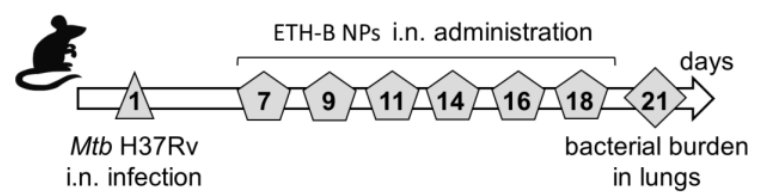

B

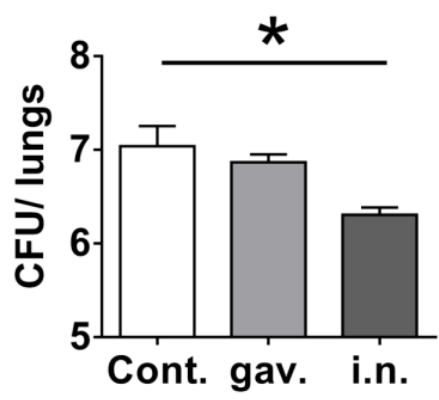

Fig. 4 Impact of ETH-B NPs on the Mtb bacterial load in the lungs of infected mice. (A) Experimental design; BALB/C mice were anesthetized and inoculated via intranasal (i.n.) route with $10^{5} \mathrm{CFU}$ of Mtb H37Rv strain contained in $20 \mu \mathrm{L}$ of PBS. At days 7, 9, 11, 14, 16 and 18 post challenge, mice received administrations of $50 \mu \mathrm{L}$ of ETH-B NPs suspension via gavage (gav.) or i.n. route (concentration of $8 \mathrm{mg} / \mathrm{mL}$ ). At day 21 post infection, lungs were harvested for bacterial burden determination by colony forming unit (CFU) counting. (B) Comparison of bacterial burden (Log scale) in lungs of 21 days Mtb infected non-treated (cont.) mice and 21 days infected mice administrated six times with ETH-B NPs via intranasal (i.n.) route or gavage (gav.). ${ }^{*}$ denote $p<0.05$ (Mann-Whitney test). 


\section{Experimental}

\section{General information}

IR spectra were obtained as solid or neat liquid on a Fourier Transform Bruker Vector 22 spectrometer. Only significant absorptions are listed. The $1 \mathrm{H}$ and $13 \mathrm{C}$ NMR spectra were recorded on Bruker Avance $300\left(300 \mathrm{MHz}\right.$ and $75 \mathrm{MHz}$, for ${ }^{1} \mathrm{H}$ and ${ }^{13} \mathrm{C}$, respectively) or Bruker Avance $400(400 \mathrm{MHz}$ and $100 \mathrm{MHz}$, for $1 \mathrm{H}$ and $13 \mathrm{C}$, respectively) spectrometers. Recognition of methyl, methylene, methine, and quaternary carbon nuclei in ${ }^{13} \mathrm{C} N M R$ spectra rests on the J-modulated spin-echo sequence. Mass spectra were recorded on a Bruker Esquire-LC. Analytical thin-layer chromatography was performed on Merck silica gel 60F254 glass precoated plates $(0.25 \mathrm{~mm}$ layer). Column chromatography was performed on Merck silica gel 60 (230-400 mesh ASTM). Diethyl ether and tetrahydrofuran (THF) were distilled from sodium/benzophenone ketyl. DMF, and $\mathrm{CH}_{2} \mathrm{Cl}_{2}$ were distilled from calcium hydride, under a nitrogen atmosphere. All reactions involving air- or water-sensitive compounds were routinely conducted in glassware which was flame-dried under a positive pressure of nitrogen or argon. Ethionamide and 4-acetylbenzoic acid were purchased from Sigma-Aldrich Chemical Co., France. 3,3,3-Trifluoropropylamine was purchased from Ugarit Chimie (France); PVA ( $88 \%$ hydrolysed, average $\mathrm{M}_{\mathrm{w}} 31,000-50,000 \mathrm{Da}$ ) was obtained from Sigma-Aldrich (Saint Quentin Fallavier, France). Chemicals obtained from commercial suppliers were used without further purification. BDM43266 was synthetized according to B. Villemagne et al. ${ }^{10}$ pKa were calculated using the MarvinSketch 6.2.2 program (ChemAxon Ldt).

\section{2-Ethyl-N-(hydroxymethyl)pyridine-4-carbothioamide (4)}

To a solution of ethionamide $(5.0 \mathrm{~g}, 30 \mathrm{mmol})$ in THF $(90 \mathrm{~mL})$ was added $37 \%$ aqueous formaldehyde $(120 \mathrm{mmol}, 4$ equiv., 9 $\mathrm{mL})$ and water $(120 \mathrm{~mL})$. The reaction mixture was stirred at room temperature for $16 \mathrm{~h}$. After removing the solvent under reduced pressure the aqueous phase was extracted with $\mathrm{CH}_{2} \mathrm{Cl}_{2}(5 \times 20 \mathrm{~mL})$. The combined organic layers were washed with brine, dried over magnesium sulfate and concentrated under reduced pressure to give the hemiaminal $\mathbf{4}$ as a yellow solid ( $3.30 \mathrm{~g}, 56 \%)$. The crude product was pure enough to be directly used in the next step. An analytical sample was obtained by silica gel column chromatography eluting with $\mathrm{CH}_{2} \mathrm{Cl}_{2} / \mathrm{MeOH}$ 97:3. Mp 100-102 ${ }^{\circ} \mathrm{C}$; ${ }^{1} \mathrm{H}$ NMR (300 MHz, DMSO$\left.\mathrm{d}_{6}\right) \delta 10.90(\mathrm{br} \mathrm{s}, 1 \mathrm{H}, \mathrm{NH}), 8.52(\mathrm{~d}, J=5.1 \mathrm{~Hz}, 1 \mathrm{H}, \mathrm{H}-6), 7.47(\mathrm{~s}$, $1 \mathrm{H}, \mathrm{H}-3), 7.43(\mathrm{~d}, J=5.1 \mathrm{~Hz}, 1 \mathrm{H}, \mathrm{H}-5), 6.26(\mathrm{t}, J=6.9 \mathrm{~Hz}, 1 \mathrm{H}$, $\left.\mathrm{OH}), 5.11\left(\mathrm{t}, J=5.4 \mathrm{~Hz}, 2 \mathrm{H}, \mathrm{HNCH}_{2} \mathrm{OH}\right)\right), 2.79(\mathrm{q}, J=7.6 \mathrm{~Hz}, 2 \mathrm{H}$, $\left.\mathrm{CH}_{2} \mathrm{CH}_{3}\right), 1.23\left(\mathrm{t}, J=7.6 \mathrm{~Hz}, 3 \mathrm{H}, \mathrm{CH}_{2} \mathrm{CH}_{3}\right) \mathrm{ppm} ;{ }^{13} \mathrm{C}$ NMR $(75$ $\left.\mathrm{MHz}, \mathrm{DMSO}-\mathrm{d}_{6}\right) \delta 195.99$ (C, C=S), 163.19 (C, C-2), $149.15(\mathrm{CH}$, C-6), 148.00 (C, C-4), $119.16(\mathrm{CH}, \mathrm{C}-3), 118.73(\mathrm{CH}, \mathrm{C}-5), 69.39$ $\left(\mathrm{CH}_{2}, \mathrm{OCH}{ }_{2} \mathrm{NCS}\right), 30.71\left(\mathrm{CH}_{2}, \mathrm{CH}_{2} \mathrm{CH}_{3}\right), 13.71\left(\mathrm{CH}_{3}, \mathrm{CH}_{2} \mathrm{CH}_{3}\right)$ ppm; IR (neat): $v=3200$ (br), 3064, 3028, 2978, 2935, 2877, $1606,1566,1548,1474,1461,1417,1398,1379,1338,1274$, $1223,1208,1186,1151,1114,1103,963,942,882,860,824$, 810, 730, $701 \mathrm{~cm}^{-1}$; MS (ESI+) $\mathrm{m} / z(\%): 197.1(100)[\mathrm{M}+\mathrm{H}]^{+}$, $167.1(80)\left[\mathrm{M}+\mathrm{H}-\mathrm{CH}_{2} \mathrm{O}\right]^{+}$; (Fig. S1,S2)
N-(Methoxymethyl)-4-(2-methyl-1,3-thiazol-4-yl)-N-(3,3,3-trifluoropropyl)benzamide (6c)

To a solution of BDM43266 ${ }^{10}$ (447 mg, $\left.1.42 \mathrm{mmol}\right)$ in anhydrous THF $(10 \mathrm{~mL})$ were sequentially added $n$ tetrabutylammonium hydrogensulfate $(48 \mathrm{mg}, 0.14 \mathrm{mmol})$ and $t$-BuOK (480 mg, $4.26 \mathrm{mmol}, 3$ equiv.) and the resulting mixture was stirred for $15 \mathrm{~min}$. Chloromethylmethyl ether (343 $\mathrm{mg}, 4.26 \mathrm{mmol}, 3$ equiv.) was then added dropwise to the suspension at room temperature. After $5 \mathrm{~min}$. stirring, $0.5 \mathrm{~N}$ $\mathrm{HCl}(10 \mathrm{~mL})$ was added and the THF was removed under reduced pressure. The aqueous residue was extracted with AcOEt $(3 \times 10 \mathrm{~mL})$. The combined organic layers were washed with brine, dried over magnesium sulfate and concentrated under reduced pressure. The residue was purified by silica gel column chromatography eluting with AcOEt/petroleum ether $4: 1$ to give methoxymethyl derivative $6 \mathrm{c}$ as a colorless oil (312 $\mathrm{mg}, 61 \%) .{ }^{1} \mathrm{H}$ NMR (300 MHz, $\left.\mathrm{CDCl}_{3}\right) \delta 7.93(\mathrm{~d}, J=8.1 \mathrm{~Hz}, 2 \mathrm{H}$, $\left.\mathrm{H}-2_{\mathrm{Ar}}, \mathrm{H}-6_{\mathrm{Ar}}\right), 7.53\left(\mathrm{~d}, J=8.1 \mathrm{~Hz}, 2 \mathrm{H}, \mathrm{H}-3_{\mathrm{Ar}}, \mathrm{H}-5_{\mathrm{Ar}}\right), 7.40(\mathrm{~s}, 1 \mathrm{H}$, $\mathrm{HC}=\mathrm{C}(\mathrm{N}) \mathrm{Ar}), 4.63\left(\mathrm{br} \mathrm{s}, 2 \mathrm{H}, \mathrm{CONCH}_{2} \mathrm{OCH}_{3}\right), 3.78(\mathrm{t}, J=7.0 \mathrm{~Hz}$, $\left.2 \mathrm{H} \mathrm{NCH} \mathrm{CH}_{2} \mathrm{CF}_{3}\right), 3.19\left(\mathrm{~s}, 3 \mathrm{H}, \mathrm{OCH}_{3}\right), 2.79\left(\mathrm{~s}, 3 \mathrm{H}, \mathrm{S}\left(\mathrm{CH}_{3}\right) \mathrm{C}=\mathrm{N}\right)$, 2.65-2.57 (m, 2H, NCH $\left.\mathrm{CH}_{2} \mathrm{CF}_{3}\right) \mathrm{ppm} ;{ }^{13} \mathrm{C} \mathrm{NMR}\left(75 \mathrm{MHz}, \mathrm{CDCl}_{3}\right)$ $\delta 172.03(\mathrm{C}, \mathrm{CON}), 166.23 \quad\left(\mathrm{C}, \mathrm{CH}_{3} \mathrm{C}(\mathrm{S})=\mathrm{N}\right), 153.86 \quad(\mathrm{C}$, $\mathrm{HC}=\mathrm{C}(\mathrm{N}) \mathrm{Ar}), 136.39\left(\mathrm{C}, \mathrm{C}-4_{\mathrm{Ar}}\right), 134.24\left(\mathrm{C}, \mathrm{C}-1_{\mathrm{Ar}}\right), 127.80(2 \mathrm{CH}, \mathrm{C}-$ 2,6 $\left.6_{\mathrm{Ar}}\right), 126.20\left(2 \mathrm{CH}, \mathrm{C}-3,5_{\mathrm{Ar}}\right), 126.25\left(\mathrm{q}, \mathrm{J}_{\mathrm{CF}}=275 \mathrm{~Hz}, \mathrm{CF}_{3}\right)$, $113.75(\mathrm{CH}, \mathrm{HC}=\mathrm{C}(\mathrm{N}) \mathrm{Ar}), 81.80\left(\mathrm{CH}_{2}, \mathrm{CONCH}_{2} \mathrm{O}\right), 55.08\left(\mathrm{CH}_{3}\right.$, $\left.\mathrm{OCH}_{3}\right), 39.75\left(\mathrm{CH}_{2}, \mathrm{NCH}_{2} \mathrm{CH}_{2} \mathrm{CF}_{3}\right), 32.31$ (q, $J_{C F}=28.0 \mathrm{~Hz}, \mathrm{CH}_{2}$, $\left.\mathrm{NCH}_{2} \mathrm{CH}_{2} \mathrm{CF}_{3}\right), 19.19\left(\mathrm{CH}_{3}, \mathrm{~S}\left(\mathrm{CH}_{3}\right) \mathrm{C}=\mathrm{N}\right) \mathrm{ppm} ;{ }^{19} \mathrm{~F} \mathrm{NMR}(188 \mathrm{MHz}$, $\mathrm{CDCl}_{3}$ ) $\delta-65.28$ ppm; IR (neat): $v=3028,2978,1645,1635$, $1610,1456,1421,1390,1343,1327,1282,1251,1221,1189$, $1169,1135,1108,1084,1039,1017,990,952, \mathrm{~cm}^{-1}$; MS (ESI+) $\mathrm{m} / \mathrm{z}$ (\%): $381.1(100)[\mathrm{M}+\mathrm{Na}]^{+}, 358.10(62)[\mathrm{M}+\mathrm{H}]^{+}$; (Fig. $\mathrm{S} 3, \mathrm{~S} 4)$.

\section{$N$-[(2-hydroxyethoxy)methyl]-4-(2-methyl-1,3-thiazol-4-yl)-N- (3,3,3-trifluoropropyl) benzamide (8)}

To a solution of hemiaminal $6 \mathrm{c}(312 \mathrm{mg}, 0.87 \mathrm{mmol})$ in ethane1,2-diol $(3 \mathrm{~mL})$ at $45^{\circ} \mathrm{C}$ was added $p$-toluenesulfonic acid (165 $\mathrm{mg}, 1.1$ equiv.) and the mixture was stirred at $40{ }^{\circ} \mathrm{C}$ for $16 \mathrm{~h}$. The reaction mixture was neutralized with a saturated aqueous solution of sodium hydrogen carbonate, and the mixture was extracted with $\mathrm{CH}_{2} \mathrm{Cl}_{2}(3 \times 10 \mathrm{~mL})$. The combined organic phases were washed with brine, dried over magnesium sulfate and concentrated under reduced pressure to give the title compound as a colorless oil (269 $\mathrm{mg}, 80 \%$ ) which was directly engaged in the next step. ${ }^{1} \mathrm{H}$ NMR (300 $\left.\mathrm{MHz}_{2} \mathrm{CDCl}_{3}\right) \delta$ $7.93\left(\mathrm{~d}, J=8.3 \mathrm{~Hz}, 2 \mathrm{H}, \mathrm{H}-2_{\mathrm{Ar}}, \mathrm{H}-6_{\mathrm{Ar}}\right), 7.53(\mathrm{~d}, J=8.3 \mathrm{~Hz}, 2 \mathrm{H}, \mathrm{H}-$ $\left.3_{\mathrm{Ar}}, \mathrm{H}-5_{\mathrm{Ar}}\right), 7.39(\mathrm{~s}, 1 \mathrm{H}, \mathrm{HC}=\mathrm{C}(\mathrm{N}) \mathrm{Ar}), 4.77\left(\mathrm{br} \mathrm{s}, 2 \mathrm{H}, \mathrm{CONCH}_{2} \mathrm{O}\right)$, $3.79\left(\mathrm{t}, J=6.4 \mathrm{~Hz}, 2 \mathrm{H}, \mathrm{NCH}_{2} \mathrm{CH}_{2} \mathrm{CF}_{3}\right), 3.72(\mathrm{t}, J=4.1 \mathrm{~Hz}, 2 \mathrm{H}$, $\mathrm{OCH}_{2} \mathrm{CH}_{2} \mathrm{OH}$ ), 3.40 (br s, $2 \mathrm{H}, \mathrm{OCH}_{2} \mathrm{CH}_{2} \mathrm{OH}$ ), 2.79 (s, $3 \mathrm{H}$, $\left.\mathrm{S}\left(\mathrm{CH}_{3}\right) \mathrm{C}=\mathrm{N}\right), 2.70-2.50\left(\mathrm{~m}, 2 \mathrm{H}, \mathrm{NCH}_{2} \mathrm{CH}_{2} \mathrm{CF}_{3}\right) 1.77(\mathrm{br} \mathrm{s}, 1 \mathrm{H}, \mathrm{OH})$ ppm; $\left.{ }^{13} \mathrm{C} \mathrm{NMR} \mathrm{(75} \mathrm{MHz,} \mathrm{CDCl}_{3}\right) \delta 172.24$ (C, CON), 166.64, (C, $\left.\mathrm{CH}_{3} \mathrm{C}(\mathrm{S})=\mathrm{N}\right), 153.98(\mathrm{C}, \mathrm{HC}=\mathrm{C}(\mathrm{N}) \mathrm{Ar}), 136.52\left(\mathrm{C}, \mathrm{C}-4_{\mathrm{Ar}}\right), 134.41(\mathrm{C}$, $\left.\mathrm{C}-1_{\mathrm{Ar}}\right), 127.99\left(2 \mathrm{CH}, \mathrm{C}-2,6_{\mathrm{Ar}}\right), 126.53\left(2 \mathrm{CH}, \mathrm{C}-3,5_{\mathrm{Ar}}\right), 113.89(\mathrm{CH}$, $\mathrm{HC}=\mathrm{C}(\mathrm{N}) \mathrm{Ar}), 80.95\left(\mathrm{CH}_{2}, \mathrm{CONCH}_{2} \mathrm{O}\right), 69.11\left(\mathrm{CH}_{2}, \mathrm{OCH}_{2} \mathrm{CH}_{2} \mathrm{OH}\right)$, $61.77\left(\mathrm{CH}_{2}, \mathrm{OCH}_{2} \mathrm{CH}_{2} \mathrm{OH}\right), 39.93\left(\mathrm{CH}_{2}, \mathrm{NCH}_{2} \mathrm{CH}_{2} \mathrm{CF}_{3}\right), 32.46$ (q, 
$\left.J_{C F}=26.7 \mathrm{~Hz}, \mathrm{CH}_{2}, \mathrm{NCH}_{2} \mathrm{CH}_{2} \mathrm{CF}_{3}\right), 19.41\left(\mathrm{CH}_{3}, \mathrm{~S}\left(\mathrm{CH}_{3}\right) \mathrm{C}=\mathrm{N}\right) \mathrm{ppm}$ (the $\mathrm{CF}_{3}$ was not detected). ${ }^{19} \mathrm{~F} \mathrm{NMR}\left(188 \mathrm{MHz}, \mathrm{CDCl}_{3}\right) \delta-65.19$ ppm; IR (neat): $v=3600-3400,3092,3028,2962,2919,1635$, $1610,1479,1462,1429,1398,1346,1328,1257,1200,1169$, $1137,1098,1083,1008,988,910,864,858,844,810 \mathrm{~cm}^{-1}$; MS $(\mathrm{ESI}+) \mathrm{m} / \mathrm{z}(\%): 411.1(100)[\mathrm{M}+\mathrm{Na}]^{+}$; (Fig. S5,S6).

\section{5-[2-(\{1-[4-(2-methyl-1,3-thiazol-4-yl)phenyl]-N-(3,3,3-} trifluoropropyl)formamido\}methoxy)ethoxy]-5-oxopentanoic acid (10)

To a solution of alcohol 8 ( $880 \mathrm{mg}, 2.27 \mathrm{mmol}$ ) in $\mathrm{CH}_{2} \mathrm{Cl}_{2}$ (18 $\mathrm{mL}$ ) was sequentially added anhydrous pyridine $(730 \mathrm{mg}, 4$ eq.), glutaric anhydride (51 mg, 2 eq.) and 4dimethylaminopyridine ( $28 \mathrm{mg}, 0.1$ eq.). The resulting mixture was stirred overnight at $20{ }^{\circ} \mathrm{C}$. The $\mathrm{CH}_{2} \mathrm{Cl}_{2}$ was then removed under reduced pressure and the mixture was taken up into water. The mixture was extracted with AcOEt $(4 \times 20 \mathrm{~mL})$ and the combined organic phases were washed with brine $(2 \times 3$ $\mathrm{mL}$ ), dried over magnesium sulfate and concentrated under reduced pressure. The residue was purified by silica gel column chromatography, eluting with petroleum ether/ ethyl acetate (80:20 to 50:50) to give compound 10 (845 mg, 74\%) as a colorless oil; ${ }^{1} \mathrm{H}$ NMR (300 MHz, $\left.\mathrm{CDCl}_{3}\right) \delta 7.89(\mathrm{~d}, J=8.0 \mathrm{~Hz}, 2 \mathrm{H}$, $\left.\mathrm{H}-2_{\mathrm{Ar}}, \mathrm{H}-6_{\mathrm{Ar}}\right), 7.60$ (d, J = 8.0 Hz, 2H, H-3 $\left.3_{\mathrm{Ar}}, \mathrm{H}-5_{\mathrm{Ar}}\right), 7.40$ (s, $1 \mathrm{H}$, $\left.\mathrm{S}\left(\mathrm{CH}_{3}\right) \mathrm{C}=\mathrm{N}\right), 4.71\left(\mathrm{~s}, 2 \mathrm{H}, \mathrm{CONCH}_{2} \mathrm{O}\right), 4.23(\mathrm{t}, J=4.0 \mathrm{~Hz}, 2 \mathrm{H}$, $\mathrm{OCH}_{2} \mathrm{CH}_{2} \mathrm{OCO}$ ), 3.79 (t, $J=6.7 \mathrm{~Hz}, 2 \mathrm{H}, \mathrm{NCH}_{2} \mathrm{CH}_{2} \mathrm{CF}_{3}$ ), 3.53 (br s, $\left.2 \mathrm{H}, \mathrm{OCH}_{2} \mathrm{CH}_{2} \mathrm{OCO}\right), 2.82\left(\mathrm{~s}, 3 \mathrm{H}, \mathrm{S}\left(\mathrm{CH}_{3}\right) \mathrm{C}=\mathrm{N}\right), 2.70-2.50(\mathrm{~m}, 2 \mathrm{H}$, $\left.\mathrm{NCH}_{2} \mathrm{CH}_{2} \mathrm{CF}_{3}\right), 2.46\left(\mathrm{t}, J=7.4 \mathrm{~Hz}, 2 \mathrm{H}, \mathrm{O}_{2} \mathrm{CCH}_{2} \mathrm{CH}_{2} \mathrm{CH}_{2} \mathrm{CO}_{2} \mathrm{H}\right), 2.41$ (t, $J=6.9 \mathrm{~Hz}, 2 \mathrm{H}, \mathrm{CH}_{2} \mathrm{CO}_{2} \mathrm{H}$ ), 1.98 (quint, $J=7.0 \mathrm{~Hz}, 2 \mathrm{H}$, $\mathrm{CH}_{2} \mathrm{CH}_{2} \mathrm{CO}_{2} \mathrm{H}$ ) ppm; $\left.{ }^{13} \mathrm{C} \mathrm{NMR} \mathrm{(75} \mathrm{MHz,} \mathrm{CDCl}_{3}\right) \delta 176.86$ (C, $\left.\mathrm{CO}_{2} \mathrm{H}\right), 172.87\left(\mathrm{C}, \mathrm{CO}_{2}\right), 172.08\left(\mathrm{C}, \mathrm{ArCO}_{2}\right), 167.58$ (C, $\left.\mathrm{CH}_{3} \mathrm{C}(\mathrm{S})=\mathrm{N}\right), 153.78(\mathrm{C}, \mathrm{HC}=\mathrm{C}(\mathrm{N}) \mathrm{Ar}), 136.18\left(\mathrm{C}, \mathrm{C}-4_{\mathrm{Ar}}\right), 134.39(\mathrm{C}$, $\left.\mathrm{C}-1_{\mathrm{Ar}}\right), 128.09\left(2 \mathrm{CH}, \mathrm{C}-3,5_{\mathrm{Ar}}\right), 126.54\left(2 \mathrm{CH}, \mathrm{C}-2,6_{\mathrm{Ar}}\right), 114.15(\mathrm{C}$, $\mathrm{HC}=\mathrm{C}(\mathrm{N}) \mathrm{Ar}), \quad 80.92 \quad\left(\mathrm{CH}_{2}, \quad \mathrm{CONCH}_{2} \mathrm{O}\right), \quad 65.91 \quad\left(\mathrm{CH}_{2}\right.$, $\left.\mathrm{NCH}_{2} \mathrm{OCH}_{2} \mathrm{CH}_{2} \mathrm{OCO}\right), 63.30\left(\mathrm{CH}_{2}, \mathrm{NCH}_{2} \mathrm{OCH}_{2} \mathrm{CH}_{2} \mathrm{OCO}\right), 40.32$ $\left(\mathrm{CH}_{2}, \mathrm{NCH}_{2} \mathrm{CH}_{2} \mathrm{CF}_{3}\right), 33.06\left(2 \mathrm{CH}_{2}, \mathrm{OCOCH}_{2} \mathrm{CH}_{2} \mathrm{CH}_{2} \mathrm{CO}_{2} \mathrm{H}\right), 32.37$ (q, $\left.J_{C F}=27.0 \mathrm{~Hz}, \quad \mathrm{CH}_{2}, \quad \mathrm{NCH}_{2} \mathrm{CH}_{2} \mathrm{CF}_{3}\right), 20.17 \quad\left(\mathrm{CH}_{2}\right.$, $\left.\mathrm{O}_{2} \mathrm{CCH}_{2} \mathrm{CH}_{2} \mathrm{CH}_{2} \mathrm{CO}_{2}\right), 19.06\left(\mathrm{CH}_{3}, \mathrm{~S}\left(\mathrm{CH}_{3}\right) \mathrm{C}=\mathrm{N}\right) \mathrm{ppm}$, the $\mathrm{CF}_{3}$ signal was masked by the aromatic carbons; ${ }^{19} \mathrm{~F} \mathrm{NMR}(188 \mathrm{MHz}$, $\left.\mathrm{CDCl}_{3}\right) \delta$-65.24 ppm; IR (neat): $v=3500-2500,1738,1708$, $1645,1610,1567,1531,1455,1421,1393,1340,1332,1291$, $1251,1223,1172,1138,1111,1087,1052,1027,1016,993$, $861,846,791,753,745,687,655 \mathrm{~cm}^{-1}$; MS (ESI-) $\mathrm{m} / z$ (\%): 501.2 (100) [M - H]'; (Fig. S7,S8).

1-[(2-ethylpyridin-4-yl)methanethioamido]methyl 5-[2-(\{1-[4(2-methyl-1,3-thiazol-4-yl)phenyl]-N-(3,3,3-trifluoropropyl) formamido\}methoxy)ethyl] pentanedioate (ETH-B codrug)

To a solution of acid 10 (538 mg, $1.07 \mathrm{mmol})$ in $\mathrm{CH}_{2} \mathrm{Cl}_{2}(6 \mathrm{~mL})$ was added at $0{ }^{\circ} \mathrm{C}$, anhydrous $\mathrm{TsOH}(184 \mathrm{mg}, 1.07 \mathrm{mmol})$ and the reaction mixture was stirred for $10 \mathrm{~min}$. $\mathrm{EDCl} . \mathrm{HCl}(328 \mathrm{mg}$, $1.71 \mathrm{mmol}$ ) and $\mathrm{HOBt}(231 \mathrm{mg}, 1.71 \mathrm{mmol})$ were then successively added and the mixture was stirred at room temperature. After being stirred for $30 \mathrm{~min}, \mathrm{~N}$-hydroxymethyl ethionamide (4) $(420 \mathrm{mg}, 2.14 \mathrm{mmol})$ was added at once. The reaction mixture was stirred at $20{ }^{\circ} \mathrm{C}$ for $24 \mathrm{~h}$ and a saturated aqueous solution of $\mathrm{NaHCO}_{3}$ was added $(5 \mathrm{~mL})$. The mixture was extracted with of $\mathrm{CH}_{2} \mathrm{Cl}_{2}(3 \times 10 \mathrm{~mL})$. The combined organic phases were washed with brine, dried over magnesium sulfate and concentrated under reduced pressure. The oily residue was purified by silica gel column chromatography, eluting with $\mathrm{CH}_{2} \mathrm{Cl}_{2}$ and then with $\mathrm{CH}_{2} \mathrm{Cl}_{2} / \mathrm{MeOH}$ (99:1) to give the title compound together some starting material. Further chromatographic purification eluting with $\mathrm{Et}_{2} \mathrm{O} / \mathrm{EtOH}$ (100:0 to $65: 1)$ provided the ETH-B codrug as a yellow oil $(238 \mathrm{mg}$, 32.7\%). ${ }^{1} \mathrm{H}$ NMR $\left(400 \mathrm{MHz}, \mathrm{CDCl}_{3}\right) \delta 9.15(\mathrm{t}, J=6.4 \mathrm{~Hz}, 1 \mathrm{H}$, CONH), $8.48\left(\mathrm{~d}, J=5.6 \mathrm{~Hz}, 1 \mathrm{H}, \mathrm{H}-6_{\text {ethio }}\right), 7.88(\mathrm{~d}, J=8.0 \mathrm{~Hz}, 2 \mathrm{H}$, $\left.\mathrm{H}-2_{\mathrm{Ar}}, \mathrm{H}-6_{\mathrm{Ar}}\right), 7.47\left(\mathrm{~d}, J=8.0 \mathrm{~Hz}, 2 \mathrm{H}, \mathrm{H}-3_{\mathrm{Ar}}, \mathrm{H}-5_{\mathrm{Ar}}\right), 7.44(\mathrm{~s}, 1 \mathrm{H}, \mathrm{H}-$ $\left.3_{\text {ethio }}\right), 7.40(\mathrm{~s}, 1 \mathrm{H}, H \mathrm{C}=\mathrm{C}(\mathrm{N}) \mathrm{Ar}), 7.32\left(\mathrm{~d}, J=5.6 \mathrm{~Hz}, 1 \mathrm{H}, \mathrm{H}-5_{\text {ethio }}\right)$, $5.74\left(\mathrm{~d}, J=6.4 \mathrm{~Hz}, 2 \mathrm{H}, \mathrm{CO}_{2} \mathrm{CH}_{2} \mathrm{NHCS}\right) 4.70\left(\mathrm{br} \mathrm{s}, 2 \mathrm{H}, \mathrm{CONCH}_{2} \mathrm{O}\right)$, 4.16 (br s, $\left.2 \mathrm{H}, \quad \mathrm{NCH}_{2} \mathrm{OCH}_{2} \mathrm{CH}_{2} \mathrm{OCO}\right), 3.77$ (br s, $2 \mathrm{H}$, $\mathrm{NCH}_{2} \mathrm{CH}_{2} \mathrm{CF}_{3}$ ), 3.47 (br s, $2 \mathrm{H}, \mathrm{NCH}_{2} \mathrm{OCH}_{2} \mathrm{CH}_{2} \mathrm{OCO}$ ), 2.81 (q, $J=$ $\left.7.6 \mathrm{~Hz}, 2 \mathrm{H}, \mathrm{CH}_{2} \mathrm{CH}_{3}\right), 2.75\left(\mathrm{~s}, 3 \mathrm{H}, \mathrm{S}\left(\mathrm{CH}_{3}\right) \mathrm{C}=\mathrm{N}\right), 2.65-2.55(\mathrm{~m}, 2 \mathrm{H}$, $\mathrm{NCH}_{2} \mathrm{CH}_{2} \mathrm{CF}_{3}$ ), $2.43\left(\mathrm{t}, J=7.2 \mathrm{~Hz}, 2 \mathrm{H}, \mathrm{O}_{2} \mathrm{CCH}_{2} \mathrm{CH}_{2} \mathrm{CH}_{2} \mathrm{CO}_{2}\right.$ ), 2.38 (t, $J=7.2 \mathrm{~Hz}, 2 \mathrm{H}, \mathrm{O}_{2} \mathrm{CCH}_{2} \mathrm{CH}_{2} \mathrm{CH}_{2} \mathrm{CO}_{2}$ ), 1.94 (quint, $J=7.2 \mathrm{~Hz}$, $2 \mathrm{H}, \mathrm{O}_{2} \mathrm{CCH}_{2} \mathrm{CH}_{2} \mathrm{CH}_{2} \mathrm{CO}_{2}$ ), $1.27\left(\mathrm{t}, J=7.6 \mathrm{~Hz}, 2 \mathrm{H}, \mathrm{CH}_{2} \mathrm{CH}_{3}\right) \mathrm{ppm}$; ${ }^{13} \mathrm{C}$ NMR (100 MHz, $\left.\mathrm{CDCl}_{3}\right) \delta 199.77$ (C, $\left.\mathrm{C}=\mathrm{S}\right), 173.43$ (C, $\mathrm{CO}_{2} \mathrm{CH}_{2}$ ), 172.71 (C, $\mathrm{CO}_{2} \mathrm{CH}_{2} \mathrm{~N}$ ), 172.29 (C, $\mathrm{ArCO}_{2}$ ), 166.54 (C, $\left.\mathrm{CH}_{3} \mathrm{C}(\mathrm{S})=\mathrm{N}\right), 164.19$ (C, C-2 ethio), $153.88(\mathrm{C}, \mathrm{HC}=\mathrm{C}(\mathrm{N}) \mathrm{Ar}), 149.12$ $\left(\mathrm{CH}, \mathrm{C}-6_{\text {ethio }}\right), 148.36$ (C, C-4 ethio $), 136.68$ (C, C- $\left.4_{\text {Ar }}\right), 134.07$ (C, C$\left.1_{\mathrm{Ar}}\right), 127.87\left(2 \mathrm{CH}, \mathrm{C}-3,5_{\mathrm{Ar}}\right), 126.45\left(2 \mathrm{CH}, \mathrm{C}-2,6_{\mathrm{Ar}}\right), 119.66(\mathrm{CH}, \mathrm{C}-$ $\left.3_{\text {ethio }}\right), 117.98\left(\mathrm{CH}, \mathrm{C}-5_{\text {ethio }}\right), 114.05(\mathrm{C}, \mathrm{HC}=\mathrm{C}(\mathrm{N}) \mathrm{Ar}), 80.83\left(\mathrm{CH}_{2}\right.$, $\left.\mathrm{CONCH}_{2} \mathrm{O}\right), \quad 68.34 \quad\left(\mathrm{CH}_{2}, \quad \mathrm{CO}_{2} \mathrm{CH}_{2} \mathrm{NHCS}\right), \quad 65.76 \quad\left(\mathrm{CH}_{2}\right.$, $\left.\mathrm{NCH}_{2} \mathrm{OCH}_{2} \mathrm{CH}_{2} \mathrm{OCO}\right), \quad 63.23\left(\mathrm{CH}_{2}, \quad \mathrm{NCH}_{2} \mathrm{OCH}_{2} \mathrm{CH}_{2} \mathrm{OCO}\right), \quad 39.97$ $\left(\mathrm{CH}_{2}, \mathrm{NCH}_{2} \mathrm{CH}_{2} \mathrm{CF}_{3}\right), 33.01\left(\mathrm{CH}_{2}, \mathrm{CH}_{2} \mathrm{CO}_{2}\right), 32.91\left(\mathrm{CH}_{2}, \mathrm{CH}_{2} \mathrm{CO}_{2}\right)$, 32.40 (q, $\left.J_{C F}=28.3 \mathrm{~Hz}, \mathrm{CH}_{2}, \mathrm{NCH}_{2} \mathrm{CH}_{2} \mathrm{CF}_{3}\right), 31.10\left(\mathrm{CH}_{2}, \mathrm{CH}_{2} \mathrm{CH}_{3}\right)$, $19.88\left(\mathrm{CH}_{2}, \mathrm{O}_{2} \mathrm{CCH}_{2} \mathrm{CH}_{2} \mathrm{CH}_{2} \mathrm{CO}_{2}\right), 19.40\left(\mathrm{CH}_{3}, \mathrm{~S}\left(\mathrm{CH}_{3}\right) \mathrm{C}=\mathrm{N}\right), 13.73$ $\left(\mathrm{CH}_{3}, \mathrm{CH}_{2} \mathrm{CH}_{3}\right)$ ppm (the $\mathrm{CF}_{3}$ signal was not detected); ${ }^{19} \mathrm{~F} \mathrm{NMR}$ (188 MHz, $\mathrm{CDCl}_{3}$ ) $\delta$-65.2 ppm; IR (neat): $v=3400-3200,2980$, $1737,1610,1598,1530,1475,1454,1339,1252,1223,1190$, $1172,1141,1127,1110,1088,1050,1016,993,964,906,859$, $845,820,726,687 \mathrm{~cm}^{-1}$; MS (ESI+) $\mathrm{m} / \mathrm{z}(\%): 411.1$ (17) $[\mathrm{M}+$ $\mathrm{Na}]^{+}, 681.2(100)[\mathrm{M}+\mathrm{H}]^{+}, 525.2(15)\left[\mathrm{M}-\mathrm{H}_{2} \mathrm{C}=\mathrm{NHCS}\left(\mathrm{C}_{7} \mathrm{H}_{8} \mathrm{~N}\right)\right]^{+}$; HRMS (ESI+) $\mathrm{m} / \mathrm{z}$ : $[\mathrm{M}+\mathrm{H}]^{+}$calcd for $\mathrm{C}_{31} \mathrm{H}_{36} \mathrm{~F}_{3} \mathrm{~N}_{4} \mathrm{O}_{6} \mathrm{~S}_{2}: 681.2023$; found, 681.1991; (Fig. S9,S10).

\section{ETH-B NPs preparation}

ETH-B NPs were prepared according to a nanoprecipitation method. Briefly, the optimized procedure was as follows: 5.0 $\mathrm{mg}$ of codrug were accurately weighed and dissolved in $300 \mu \mathrm{l}$ acetone. This organic phase was added dropwise into an aqueous phase $(5.0 \mathrm{~mL}$ MilliQ water containing $1 \mathrm{wt} \%$ PVA) and stirred magnetically at room temperature until complete evaporation of the organic solvent. The NP suspension was further concentrated up to $8.0 \mathrm{mg} / \mathrm{mL}$ under $\mathrm{N}_{2}$ flow. All samples were prepared in duplicate.

Individual particle tracking and NPs concentration measurements by NTA 
The NPs concentration and stability upon dilution were investigated by NTA analysis (NanoSight LM10 Instrument, Malvern Instruments Ltd, Orsay, France), combining a conventional optical microscope with a laser to illuminate the NPs in Brownian motion in a defined volume. Of main interest here, NPs could be visualized one by one, in a concentration range between $10^{6}$ and $10^{9}$ particles $/ \mathrm{mL}$. Mean hydrodynamic diameters, size distributions and concentration of ETH-B NPs were measured by NTA in the concentration range of 100-0.1 $\mu \mathrm{g} / \mathrm{mL}$. Each sample was measured 5 times for 60 seconds. Results were reported as mean diameter \pm SD .

\section{Cryo-TEM imaging}

$5 \mu \mathrm{l}$ of ETH-B NPs suspensions were deposited onto a 200 mesh copper grid and flash-frozen in liquid ethane cooled down at liquid nitrogen temperature. Cryo-TEM images were acquired on a JEOL 2200FS energy-filtered $(20 \mathrm{eV})$ field emission gun electron microscope operating at $200 \mathrm{kV}$.

\section{${ }^{1} \mathrm{H}$ NMR study of NPs after preparation}

NPs were centrifuged at $30,000 \mathrm{~g}$ for $10 \mathrm{~min}$, both the pellets and the supernatants were recovered and lyophilized. ${ }^{1} \mathrm{H} N M R$ studies confirmed that no degradation took place during NP preparation.

\section{Stability test of NPs in different physiological media.}

Prior to the stability tests, different physiological media were prepared, including $10 \mathrm{mM}$ phosphate buffer saline (PBS) at $\mathrm{pH}$ 7.4 and 1.2. Human serum albumin (HSA, $10 \mathrm{mg} / \mathrm{mL}$ ) which is the most abundant protein in the blood was added to PBS to better mimic the biological environment. NPs containing 1 $\mathrm{mg} / \mathrm{mL}$ ETH-B were diluted in the PBS $(\mathrm{pH} 7.4$ and $\mathrm{pH} 1.2)$ with or without HSA. The mean diameters of ETH-B NPs were characterized by dynamic laser scattering (DLS) after incubation at $37^{\circ} \mathrm{C}$ for 0,6 , and $24 \mathrm{~h}$.

\section{In vivo efficacy of ETH-B NPs}

6-Week old Balb/C female mice were purchased from Janvier (Le Genest-Saint-Isle, France) and were maintained in the animal facility of the Pasteur Institute of Lille, France (Agreement B59350009). The project received ethical approval by French Committee on Animal Experimentation and the Ministry of Education and Research (00579.01 approved on December $2^{\text {nd }} 2015$ and APAFIS\#10232-2017061411305485 v6 approved on September 2018) and all experiments were performed in accordance with relevant guidelines and regulations.

8-Week-old BALB/c mice (4 mice per group) were inoculated with Mtb H37Rv via the i.n. route $\left(10^{5} \mathrm{CFU} / 20 \mu \mathrm{l}\right)$ as described. ${ }^{[18]}$ On day 7, 9, 11, 14, 16 and 18-post infection, mice were administrated via gavage or i.n. route with $50 \mu \mathrm{l}$ of ETH-B NPs (concentration of $8 \mathrm{mg} / \mathrm{mL}$ ). At day 21, mice were euthanized and lungs were homogenized in a tube containing
$1 \mathrm{~mL}$ of $2.5-\mathrm{mm}$ diameter glass beads and and $1 \mathrm{~mL}$ of PBS using an MM300 bead beater apparatus (Qiagen) for 20 minutes. Ten-fold serial dilutions (from $10^{-2}$ to $10^{-9}$ ) of each sample were plated onto $7 \mathrm{H} 11$ medium agar plates (Difco) supplemented with $10 \%$ oleic acid-albumin-dextrose-catalase (OADC, Difco). After a three-week growth at $37^{\circ} \mathrm{C}$, CFUs were determined at the appropriate dilution allowing optimal colony enumeration.

\section{Conflicts of interest}

There are no conflicts to declare.

\section{Acknowledgements}

Financial support for this work was provided by the European Community (CycloN Hit Grant no 608407, ERC-STG INTRACELLTB Grant no 260901), the Agence Nationale de la Recherche (ANR-10-EQPX-04-01, ANR-14-CE08-0017, ANR-14CE14-0027-01, the Feder (12001407 (D-AL) Equipex Imaginex BioMed), the Fondation pour la Recherche Medicale (SPF20170938709) and the Region Nord Pas de Calais (convention no 12000080).

\section{Notes and references}

1 A. E. DeBarber, K. Mdluli, M. Bosman, L.-G. Bekker, C. E. Barry, $3^{\text {rd }}$, Proc. Natl. Acad. Sci. U. S. A. 2000, 97, 9677.

2 S. Thee, A. J. Garcia-Prats, P. R. Donald, A. C. Hesseling, H. S. Schaaf, Tuberculosis 2016, 97, 126.

3 Ethionamide, Tuberculosis 2008, 88, 106.

4 L. G. Dover, A. Alahari, P. Gratraud, J. M. Gomes, V. Bhowruth, R. C. Reynolds, G. S. Besra, L. Kremer, Antimicrob. Agents Chemother. 2007, 51, 1055.

5 G. Ramachandran, S. Swaminathan, Drug Saf. 2015, 38, 253.

6 T. A. Vannelli, A. Dykman, P. R. Ortiz de Montellano, J. Biol. Chem. 2002, 277, 12824.

7 A. R. Baulard, J. C. Betts, J. Engohang-Ndong, S. Quan, R. A. McAdam, P. J. Brennan, C. Locht, G. S. Besra, J. Biol. Chem. 2000, 275, 28326.

8 N. Willand, B. Dirié, X. Carette, P. Bifani, A. Singhal, M. Desroses, F. Leroux, E. Willery, V. Mathys, R. Déprez-Poulain, G. Delcroix, F. Frénois, M. Aumercier, C. Locht, V. Villeret, B. Déprez, A. R. Baulard, Nature Med. 2009, 15, 537.

9 M. Flipo, M. Desroses, N. Lecat-Guillet, B. Dirié, X. Carette, F. Leroux, C. Piveteau, F. Demirkaya, Z. Lens, P. Rucktooa, V. Villeret, T. Christophe, H. K. Jeon, C. Locht, P. Brodin, B. Déprez, A. R. Baulard, N. Willand, J. Med. Chem. 2011, 54, 2994.

10 B. Villemagne, M. Flipo, N. Blondiaux, C. Crauste, S. Malaquin, F. Leroux, C. Piveteau, V. Villeret, P. Brodin, B. O. Villoutreix, O. Sperandio, S. H. Soror, A. Wohlkönig, R. Wintjens, B. Déprez, A. R. Baulard, N. Willand, J. Med. Chem. 2014, 57, 4876-4888.

11 T. V. Volkova, S. V. Blokhina, A. V. Sharapova, M. V. Ol'khovich, G. L. Perlovich, Thermochim. Acta 2016, 640, 1.

12 J. Wankar, G. Salzano, E. Pancani, G. Benkovics, M. Malanga, F. Manoli, R. Gref, E. Fenyvesi, I. Manet, Intern. J. Pharm. 2017, 531, 568.

13 C. A. Kerantzas, W. R. Jacobs, Jr, MBio 2017, 8, e01586-16, https://doi.org/10.1128/mBio.01586-16. 
14 I. A. Aljuffali, C.-F. Lin, C.-H. Chen, J.-Y. Fang, Expert Opin. Drug Delivery 2016, 13, 1311.

15 N. Das, M. Dhanawat, B. Dash, R. C. Nagarwal, S. K. Shrivastava, Eur. J. Pharm. Sci. 2010, 41, 571.

16 R. Pandey, G. K. Khuller, J. Antimicrob. Chemother. 2005, 55, 430.

17 G. Salzano, J. Wankar, S. Ottani, B. Villemagne, A. R. Baulard, N. Willand, P. Brodin, I. Manet, R. Gref, Intern. J. Pharm. 2017, 531, 577.

18 J. Costa-Gouveia, E. Pancani, S. Jouny, A. Machelart, V. Delorme, G. Salzano, R. lantomasi, C. Piveteau, C. J. Queval, O.-R. Song, M. Flipo, B. Deprez, J.-P. Saint-André, J. Hureaux, L. Majlessi, N. Willand, A. Baulard, P. Brodin, R. Gref, Sci. Rep. 2017, 7, 5390.

19 A. H. Khans, H. Bungaard, Intern. J. Pharm. 1991, 71, 31

20 H. Bungaard, M. Johansen, J. Pharm. Sci. 1980, 69, 44.

$21 \mathrm{H}$. Bundgaard, M. Johansen, Intern. J. Pharm. 1984, 22, 45.

22 M. Johansen, H. Bundgaard, Arch. Pharm. Chemi, Sci. Ed. 1979, 7, 175.

23 I. H. Pitman, Med. Res. Rev. 1981, 1, 189.

24 S. S. Dhareshwar, V. J. Stella, J. Pharm. Sci. 2008, 97, 4184.

25 H. Böhme, H.-H. Hotzel, Arch. Pharm. 1967, 300, 241.

26 C. Giordano, A. Belli, Synthesis 1975, 789.

27 S. Majumdar, K. B. Sloan, Synth. Commun. 2006, 36, 3537.

28 E. Buchy, S. Valetti, S. Mura, J. Mougin, C. Troufflard, P. Couvreur, D. Desmaële, Eur. J. Org. Chem. 2015, 202.

29 W. J. Roberts, K. B. Sloan, Heterocycl. Chem. 2002, 39, 905.

30 W. Danikiewicz, R. Szmigielski, Synth. Commun. 2001, 31, 3047.

31 C. M. Samour, J. F. Reinhard, J. A. Vida, J. Med. Chem. 1971 14, 187.

32 G. M. Szczech, P. Furman, G. R. Painter, D. W. Barry, K. Borroto-Esoda, T. B. Grizzle, M. R. Blum, J. Sommadossi, R. Endoh, T. Niwa, M. Yamamoto, C. Moxham, Antimicrob. Agents Chemother. 2000, 44, 123.

33 C. Ladavière, R. Gref, Nanomedecine 2015, 10, 3033.

34 A. Machelart, G. Salzano, X. Li, A. Demars, A.-S. Debrie, M. Menendez-Miranda, E. Pancani, S. Jouny, E. Hoffmann, N. Deboosere, I. Belhaouane, C. Rouanet, S. Simar, S. Talahari, V. Giannini, B. Villemagne, M. Flipo, R. Brosch, F. Nesslany, B. Deprez, E. Muraille, C. Locht, A. R. Baulard, N. Willand, L. Majlessi, R. Gref, P. Brodin, ACS Nano 2019, 13, DOI: 10.1021/acsnano.8b07902. 